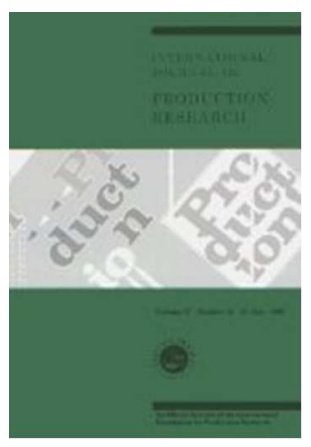

\title{
Study of supply chain management in the automotive industry: a bibliometric analysis
}

\begin{tabular}{|r|l|}
\hline Journal: & International Journal of Production Research \\
\hline Manuscript ID: & TPRS-2012-IJPR-0153.R1 \\
\hline Danuscript Type: & Original Manuscript \\
\hline Complete List of Authors: & $\begin{array}{l}\text { Gonzalez-Benito, Javier; Universidad de Salamanca, Dpto. Administracion y } \\
\text { Economia de la Empresa } \\
\text { Lannelongue, Gustavo; University of Salamanca, } \\
\text { Alfaro-Tanco, José; Universidad de Navarra, Dpto. de Empresa }\end{array}$ \\
\hline Keywords: & SUPPLY CHAIN MANAGEMENT, OPERATIONS MANAGEMENT \\
\hline Keywords (user): & automotive industry, literature review \\
\hline & \\
\hline
\end{tabular}




\section{Study of supply chain management in the automotive industry: a bibliometric} analysis*

Corresponding Author:

$$
\begin{gathered}
\text { Javier González-Benito } \\
\text { Universidad de Salamanca } \\
\text { +34923294500 ext3002 } \\
\text { javiergb@usal.es }
\end{gathered}
$$

* This research was funded by the Spanish Government and FEDER funds through research project ECO2010-21078 and the "Cátedra de Empresa VW-Navarra Universidad de Navarra". 


\section{Study of supply chain management in the automotive industry: a bibliometric analysis}

\section{Introduction}

According to the Organisation Internationale des Constructeurs d'Automobiles $\left(\mathrm{OICA}^{1}\right)$, almost 78 million cars and commercial vehicles were made in the world in $2010^{2}$, with the estimated generation over 8 million direct jobs in the assembly and manufacture of components, more than $5 \%$ of the world's industrial employment, and almost five times more in indirect jobs ${ }^{3}$. In the European Union, which accounts for more than a fourth of global output, the Association des Constructeurs Européens $d^{\prime}$ Automobiles (ACEA ${ }^{4}$ ), based on figures for 2007, indicates 3.5 million jobs, $10.2 \%$ of all the EU's industrial jobs, accounting for 5.6\% of all employment (ACEA, 2011). In the United States, another major manufacturing country, in 2008 this sector was estimated to make a contribution of between $2 \%$ and $3 \%$ of the country's gross domestic product, which means 1.7 million direct jobs and over 8 million indirect jobs, around $4.5 \%$ of private sector employment (Hill et al. 2010). Although 2008 and 2009 have recorded a small downturn in the growth trend in this sector ${ }^{5}$, these data reflect the economic importance of the automotive industry and explain the need and interests involved in researching improved ways of managing and organising all the processes involved in the production of motor vehicles.

Since the end of the 1980s, the management of procurement and supplies has been acquiring special importance in industrial organisations. It has ceased to be considered a purely administrative task and is now acknowledged for its strategic importance (Reck \& Long, 1988; Spekman et al., 1992; Welch \& Kayak, 1992; Thompson, 1996). Proof of this has been the conceptual and empirical development of several management approaches or theories that, in one way or another, have sought to establish successful behavioural guidelines in this area of corporate decision-making: partnership sourcing (Ellram, 1990), just-in-time (JIT) purchasing (Ansari \& Modarress, 1986, 1988), comakership (Bevan, 1987), reverse marketing (Leenders \& Blenkhorn, 1988), lean supply (Lamming, 1993), and, adopting a much more comprehensive and integral view of the entire supply chain, supply chain management (Harland, 1996; Mentzer et al. 2001; Cigolini et al., 2004). The interest aroused by the study of an organisation's supply chains and outside relations is readily apparent in several literature reviews (Waters-Fuller, 1995; Croom et al., 2000; Ho et al., 2002; Burgess et al., 2006; Giunipero et al., 2008; Soni \& Kodali, 2011), and has now become a key area of research in Operations Management (Alfalla-Luque \& Medina-Lopez, 2009).

\footnotetext{
${ }^{1}$ Founded in Paris in 1919 to defend the sector's interests, it is referred to in English as the International Organization of Motor Vehicle Manufacturers.

${ }^{2}$ See the data on the global production of cars and commercial vehicles on the OICA website, http://oica.net/category/production-statistics/

${ }_{3}^{3}$ Information available on the OICA website, http://oica.net/category/economic-contributions/auto-jobs/

${ }^{4}$ Founded in 1996 to replace theComité des Constructeurs du Marché Commun, with its remit being to defend the interests of European manufacturers, it is referred to in English as the European Automobile Manufacturers' Association.

${ }^{5}$ See figures for the global production of cars and commercial vehicles on the OICA website, http://oica.net/category/production-statistics/
} 
This paper focuses on the interface between these two study areas: the automotive industry and supply chains. The aim involves adopting a bibliometric standpoint to analyse the scholarly literature that addresses the study of supply chains within the specific ambit of the automotive industry. This will allow identifying the what, how and where of research into this topic. To do so, we shall analyse the academic papers included in the Business Source Complete research database, which indexes more than 1,300 journals related to business management. The main interest of this paper, as with the majority of bibliometric studies, is that it allows knowing and assessing the research conducted so far, while at the same time helping to identify current weaknesses and future opportunities. Moreover, studies of this nature help prospective researchers to situate and contextualise their contributions to the field of study in question.

The paper is organised into six sections. Section 2 describes the methodology used in the study. Sections 3, 4 and 5 focus on respectively elucidating the what, how and where of the research into supply chain management in the automotive industry. Section 6 summarises the main conclusions, while at the same time singling out some of the study's limitations, which in turn pose certain challenges for future research.

\section{Method}

The study has centred on the scholarly contributions published through to 2011 and indexed in the Business Source Complete database. This database indexes more than 1,300 journals within the fields of business management and economics. We noted beforehand that some of the more representative journals in the field of operations management that might potentially publish more papers on the chosen topic (e.g., Journal of Operations Management, International Journal of Operations and Production Management, International Journal of Production Research) were first indexed in the 1980 s or early 1990s. We therefore concluded that this database would provide a reasonably accurate view of the research conducted accordingly over the past twenty years.

A search was therefore conducted using two keywords, 'supply chain' and 'automotive', whereby we called up all those contributions that mentioned both terms in any one of the registered fields in the database (title, keywords, abstract, authors' details, etc.). The only further restrictions were that they should be papers published in scholarly journals and had been subject to a peer review process. In January 2012, these criteria generated 477 papers overall. Regarding the subsequent work of classifying and ordering, each one of these papers was read and analysed by at least two researchers separately, with any differences of opinion being resolved by the intervention of a third.

Largely due to the use of such open search criteria, the process of analysis and classification also involved a screening of the initial sample, with 73 papers being discarded because although they contained the keywords they clearly did not address our subject of study. This is explained by the fact that, for example, some of the words appeared solely in the authors' registration details, they received only a cursory mention in the text or they appeared erroneously in the paper's industrial classification codes (e.g., as 'except automotive'). The final number of papers considered in this research therefore amounted to 404. 
The papers were drawn from 136 different journals, although 91 of these provided just one paper, 15 provided two and eight provided three, with over $60 \%$ of the papers being concentrated in 22 journals as per the distribution contained in Table 1 . The first journals not specialising in the automotive sector that appear on the list are considered leading publications that are highly representative within the field of operations management (Theoharakis et al., 2007; Meredith et al., 2011).

\section{--- TABLE 1 ---}

Regarding the chronological distribution of the papers analysed, Figure 1 shows that the series begins in 1992, and there is a general increase of some significance at the start of the new millennium. As of 2004, the level of 30 papers per year has been exceeded, attaining a higher level (44 papers) in 2008. It seems reasonable to link this increase to the appearance of specialist journals in the sector, such as the International Journal of Automotive Technology and Management.

\section{--- FIGURE 1 ---}

\section{What is investigated? Content of the research}

Long-term integration and cooperation involving the different players in a supply chain have been the basis or the common denominator for the different approaches and theories of the management of supplies and procurement undertaken in recent years. This notion of cooperation was initially presented as a break with the traditional paradigm in which a manufacturer did not look beyond its immediate suppliers, considering them to be opportunistic agents to be kept at arm's length and basing the majority of its decisions on price (Johnston \& Lawrence, 1988; Bothe, 1989; Sako, 1992). This cooperative platform implies or enables implementing another series of schemes that are advantageous to the organisation: (1) better programming and timing of production and logistics, reducing stocks and increasing the capacity for service (e.g., Samaranayake \& Toncich, 2007); (2) it is therefore essential to develop initiatives and systems to guarantee the quality and reliability of supplies and risk management (e.g., Foster, 2008); (3) accordingly, it is important to make the right choice of suppliers based on capabilities and not just on price (e.g. Chen, 2011); (4) once we cooperate with the right suppliers, we can engage them in the design and development of new products (e.g., Wynstra et al., 2010); (5) the development of suppliers may be expedient to help them attain the required levels (e.g., Krause et al., 2007); (6) and all this allows addressing environmental issues from a more global perspective (e.g., Handfield et al., 2005). Furthermore, account should be taken of the role information systems and technologies play as facilitators for the implementation and proper operation of many of these practices (e.g., Zhang et al., 2011).

This distinction between cooperative practices, practices related to quality and to the programming of production and logistics, and to the development and implementation of suppliers, and the environment or the application of information technologies is consistent with those scholarly articles that have covered those component aspects of approaches such as supply chain management (e.g., Scannell et al., 2000; Min \& Mentzer, 2004; Tracey et al., 2004; Chen \& Paulraj, 2004) or lean supply or JIT purchasing (e.g. Lamming, 1993; González-Benito \& Spring, 2000), as it allows 
classifying and ordering the different constructs and practices contained in them. Therefore, taking account of this structure underpinning the new management theories and approaches that have emerged in recent years, we have chosen to identify the nine thematic areas contained in Figure 2 in order to classify the papers analysed in this research. In addition to the papers that specifically address one or more of the eight topics considered in the small ellipses, there are other papers that adopt a more general perspective, describing new approaches, considering or examining new arrangements of supply chains or analysing new challenges or perspectives. This has led to the consideration of an additional category (large ellipse that encompasses all the others) for these contributions of a more generic nature.

\section{--- FIGURE 2 ---}

Table 2 shows the number of papers classified in each thematic category. Although it is common for a paper to refer at some stage to matters involving different thematic areas, the classification was made according to their aim and basic contribution. This meant that a large number of the papers fitted into a single topic area. Nevertheless, there were others that had to be assigned to more than one. For example, some papers focus on the application to development of information systems, albeit applied specifically to the joint development of products between assembly and suppliers, and make contributions in both directions. This means that the sum total of papers assigned to different areas in Table 2 exceeds the actual number of papers contained in Table 1.

--- TABLE 2 ---

Regarding the papers on a general theme, Figure 3 reveals a growing trend through to 2006, followed by a downward trend that has finally been broken in 2011 . One cannot therefore speak of a clear trend. The papers that stand out in those first years are the ones dedicated to analysing the changes generated in the arrangement and management of supply chains by the adoption of the Japanese model (e.g., Turnbull et al., 1992; Bhattacharya et al., 1996) or the tendency to outsource production operations (e.g., Collins \& Bechler, 1999), and more recently, the effect globalisation is having on industry (e.g., Hatani, 2009), the location and relocation of production facilities (e.g., Hammami et al., 2009; Danese \& Vinelli, 2009) or geographic concentration through modular consortia, shared premises, procurement parks or clusters (Reichhart \& Holweg, 2006; Doran et al., 2007). The analysis of these topics from a global, general and regulatory perspective is increasingly less frequent as, generally speaking, the approaches and issues involved have been widely assumed and disseminated. The opportunity in this field lies instead in the analysis of the concrete realities and specificities of different geographic and legislative contexts, in a search for exceptions and peculiarities.

\section{--- FIGURE 3 ---}

The papers on relational issues are the second most frequent (Table 2). Although this subject matter has undergone several highs and lows (Figure 3), it does not appear to have lost its appeal, recording an upward trend over the past two years. Highlights within this sphere are the papers that have studied the determinant factors and the consequences and implications of the ever greater tendency for cooperation between suppliers and customers (e.g., Cousins \& Crone, 2003; Lockström et al., 2010) and 
those that have analysed the power relationships within the chain and have stressed the dominant and focal nature of assemblers, when looking both upstream and downstream on the value chain (e.g., Johnsen \& Ford, 2005). While many papers within this ambit have studied the direct relationship between supplier integration and certain variables understood as antecedents or consequences, the papers that have addressed these relations from a contingent perspective are few and recent, including the study of possible moderators (e.g., Wong et al., 2011; Dong-Hua \& Zailani, 2011). The majority of the papers adopt a dyadic perspective, focusing on one level on the chain and its direct suppliers, whereby another opportunity in this sphere lies in superseding this level of analysis.

The subject matters related to the search for greater involvement of suppliers in dealings have received less attention, especially regarding the selection and assessment of suppliers and their development (Table 2). Although the papers on the design and development of new products are somewhat more numerous, in general there has been a certain decline in these three topics over the past four years (Figure 3). Special note should be taken of the characteristics and facilitators and inhibitors of new ways of joint working that cater for the exchange of information, the generation of shared know-how and the breakdown of geographic barriers (e.g., Zirpoli \& Caputo, 2002; Johansson, 2009). This means that the overlapping between this subject matter and the topic referring to information systems and technologies is a natural field for development (e.g., Bertoni \& Larsson, 2011).

Although quality does not stand out as a thematic area (Table 2), it does record an upward trend (Figure 3). Nevertheless, the omnipresent papers centred on an analysis of the quality certifications specific to the sector or on the development of the approaches and tools particular to total quality management (e.g., Curkovic et al., 2000; Johnson, 2002) have in recent years been producing articles focusing on the analysis, measurement and control of risks in the supply chain (Blackhurst et al., 2008; Canbolat et al., 2008). We can therefore attribute the growing tendency of research in this field to the consolidation of risk management as a key aspect in the management of supply chains in the automotive industry.

Those papers, generally with a more technical bias, focused on the production scheduling and logistics management are the most frequent ones (Table 3), as for among other reasons they attract the interest of those researchers with a more quantitative profile. Although the trend is not linear, it does appear to be a subject matter that is on the increase (Figure 3). There have been two traditional topics within this ambit: coordination and synchronisation between the different echelons of the chain for achieving greater stability in intra and inter-organisational flows (e.g., Arshinder \& Deshmukh, 2007; Coronado et al., 2008) and the adaptation of supply chains towards models that allow working to order within reduced timescales, known as built-to-order systems, (Holweg \& Miemczyk, 2002; Roehrich et al., 2011). A feature in recent years has been the interest aroused by all those matters related to the outsourcing of logistics operations undertaken by the main firms in the sector (Göl \& Çatay, 2007; Klingenberg \& Boksma, 2010).

Papers with an environmental subject matter began to appear in 2001 (Figure 3). Although they do not carry a great weight overall (Table 2), they have not ceased to feature since then. The development can be considered parallel to that of quality, albeit 
discordant by a number of years. Hence the reason environmental certifications attract great interest (e.g., Delmas \& Montiel, 2009) and it is worth considering that the analysis of environmental risks will provide major research opportunities in the future. The current challenge lies in closing the procurement cycle by achieving closed supply chain loops, whereby the most efficient recovery possible will be made of vehicles at the end of their useful lives through the establishment of reverse logistics systems (e.g., Kumar \& Putnam, 2008; Aitken \& A. Murray, 2010).

Given their mainstream nature regarding all the other subject areas, the development and application of information systems and technologies have received significant interest (Table 2), although it is also true to talk of a certain decline in recent years. Those papers of a more strategic nature focus on studying and highlighting the possibilities and effects of new technologies and inter-organisational systems, especially for improving the information flows in supply chains (e.g., Chi et al., 2008; Becker et al., 2010). Their potential for achieving a more effective and efficient management of the information spread out along the chain is a major research opportunity, largely with a view to driving innovation in industry. Another series of papers with a more technical slant focuses on the development of such systems, proposing innovative designs and architectures (e.g., Grefen et al., 2009; Vujasinovic et al., 2009).

\section{How is it investigated? Methodological approaches}

Within the field of business administration and, specifically, of operations management, there are myriad research methods and approaches that tend to be used for generating knowledge (Meredith et al., 1989; Flynn et al., 1990; Easterby-Smith et al., 1991). Bearing in mind this diversity, our analysis classifies the papers into six categories:

- Theoretical. That which addresses an issue based largely on an analysis of the literature and prior contributions and/or the author's deductions or lines of reasoning, but does not provide any kind of empirical analysis.

- Software development. These can be understood as a type of theoretical work, albeit presenting the design and/or development of some form of software tool or program for a business decision or activity.

- Mathematical model. Here, too, we are dealing with a type of theoretical work, but one that proposes the mathematical modelling of a specific problem or business context upon which several inferences are made.

- Case studies. This is the first type of work with empirical content that uses detailed information on one or more firms, plants, supply chains, relationships or other units of analysis. The data gathering techniques often used involve visits, open or semistructured interviews and personal experience.

- Surveys. This is a second type of work with empirical content that contains less detailed and more structured information on a higher and more representative number of the aspects analysed, frequently through questionnaires or interviews with close-ended questions.

- Secondary sources. This is a third type of empirical work in which the authors do not directly gather the information used, but instead they have collected it from other indirect sources, such as databases, public registers or public documents.

Each paper was classified according to the methodological approach used. Given that some of them combine different approaches, such as, for example, case studies and 
surveys or case studies and mathematical modelling, they were grouped under both approaches. A subsequent calculation was made of the percentage of papers classified under an approach with regard to the overall number of articles in each approach, both in general and segmented by thematic areas. The result is presented in Figure 4.

\section{--- FIGURE 4 ---}

Regarding the papers as a whole, empirical works account for $60 \%$ (first graph in Figure 4), with case studies prevailing over surveys. Case studies are suitable for exploring new issues that are still without clear theoretical models and for formulating hypotheses (Eisenhardt, 1989; McCutcheon \& Meredith, 1993; Yin, 1989), while surveys are tools designed for verifying these hypotheses and for determining the validity of the theories developed (Bryman, 1989). In fact, the former belong to the so-called interpretive paradigm and the latter to the so-called positivist paradigm (Creswell, 1994). The greater weight of case studies over surveys leads to the conclusion that, regarding the study of supply chains in the automotive industry, we are still at a stage that is essentially exploratory and one of theoretical construction. It is also noteworthy that the use of secondary information sources is, however, very infrequent, perhaps because most databases and public reports focus on financial aspects, and the information they contain on supply chain management is either non-existent or extremely scarce.

Concerning those papers of a more theoretical nature, our attention is drawn to the low weight of mathematical modelling cases, which do not reach $14 \%$ (first graph in Figure 4). As this is the main expression of the approach referred to as scientific or quantitative, with a long-standing tradition in the study of operations management (Meredith et al., 1989) and fed by numerous leading journals, a greater presence is to be expected. In order to delve further into this issue, a distinction was made between those papers in which the automotive industry is only an illustration or a testing ground regarding the issue in hand and those that are fully focused on this industry or study specific aspects pertaining to it. Forty-one percent of the papers that develop mathematical models use the automotive sector solely as a testing ground for the algorithms considered or as an illustration, whereas in fact they address issues applicable to different industrial contexts and sectors. The percentage of all the other methodological approaches never reaches $15 \%$. This does not therefore suggest a decline in more quantitative approaches but rather indicates that this does not seem to be the best way of tackling the specific issues and problems of the automotive industry.

The development of applications and tools has a very small weight (3.1\%), which is understandable when we consider that this work rarely goes beyond the mechanisation of a specific process and generates knowledge that leads to a better understanding of a business problem or situation. This means that in many cases the work involved pertains more to the realm of consulting than to academia.

When we consider segmentation by thematic areas (Figure 4), the pattern is generally repeated, although there are certain aspects worth highlighting. In some subject areas, especially in relational matters and those linked to quality, surveys have gained greater weight compared to case studies. Returning to the discussion considered earlier, this reflects greater theoretical maturity in both areas. For example, relational aspects have significant theoretical bases, such as transaction costs theory (Williamson, 1979), agency theory (Jensen \& Meckling, 1976) or the resources and capabilities approach 
(Dyer, 1997), which explains why we have now entered a more confirmatory and positivist phase.

Mathematical modelling attains greater weight in matters related to production programming and logistics and to environmental management. In the former case, this is because the issues addressed are of a more operational and less strategic nature and, therefore, easier to harness with quantitative tools. If we bear in mind that the environmental category also involves issues of a more technical nature, such as reverse logistics and the establishment of closed cycles for production flows, it is hardly surprising that mathematical modelling is gaining ground.

Insofar as software developments are concerned, it is only to be expected that they are more frequent in papers related to the application of information systems and technologies to supply chain management. The greater weight of this methodological approach regarding other thematic areas in articles on product design and development reflects, as noted earlier, the importance of developing tools that facilitate joint operations and the management of shared know-how in order to improve the launch of products in the automotive industry.

\section{Where is it investigated? Geographic scope of research and researchers}

Regarding the location of the research, two variables have been analysed: (1) the geographic context analysed in the papers considered and (2) the geographic provenance of the researchers involved. Regarding the first point, a country-based enumeration was made of the papers referring to or located within each one, either because they analyse problems specific to that country or because they use empirical data collected there. When a paper refers to two countries, each county was allotted $1 / 2 \mathrm{a}$ mention, and so on if it referred to three or four. With a few to operationalising the calculation, three wider categories were also considered: Europe, regions of Asia and the whole world. The 85 papers that make no reference at all to any geographic setting were grouped into a category of their own. Figure 5 shows the 15 main contexts analysed according to each one's percentage weight, both on a general basis and according to each thematic area. A note is also made of the total number of locations studied in each category.

\section{--- FIGURE 5 ---}

Regarding the sum total of papers studied, almost a third of the papers focus on the United States and the United Kingdom, with this figure rising to $40 \%$ when no account is taken of those papers that do not refer to a specific geographic context. It is generally noted that the countries or regions that occupy the highest positions are those with a greater tradition and weight as car producing economies. Almost $8 \%$ of the papers refer to Europe as a whole, and five out of Europe's eight largest producers (ACEA, 2011) appear among the fifteen main settings analysed. There are also emerging countries, such as China, Brazil and India, which have gained enormously in importance in recent years as manufacturers of car and motor vehicles. According to 2010 data published by 
the $\mathrm{OICA}^{6}$, these three countries account for a third of global output. The pattern tends to be repeated when considering segmentation by thematic areas. Along these lines, mention should be made of the weight the US has in terms of articles on quality, reliability and management and risk. A possible reason for this is the country's preeminence in the development of standards such as QS9000. The papers on production programming and logistics are the ones that refer the least to specific geographic settings, which is understandable when we consider that this category has a prevalence of the mathematical modelling of generic issues that affect any context.

With a view to delving further into an appraisal of the degree of geographic specificity of the research conducted in this field, computation was made of the percentage of papers that in each thematic area overcame national barriers and focused on at least two different countries. This percentage, which for the sum total of papers stands at $14.9 \%$, is significant in the papers of a general nature, which record a figure of $29.1 \%$, and in the articles on environmental management, at $21.2 \%$. Nonetheless, these are low percentages that suggest possible difficulties when extrapolating and generalising the results beyond a specific national context. These percentages are reduced even further if we consider solely those papers with an empirical grounding. Therefore, the drafting of multi-country papers is seen both as an opportunity and as a requirement for the generation of knowledge on supply chain management in the automotive industry.

Regarding the second variable, the provenance of the researchers producing the papers, computation was made for each country of the number of papers published by resident researchers. If a paper has two authors from centres in different countries, the allocation was $1 / 2$ for each country, following a similar criterion according to the increasing number of authors. Figure 6 presents, according to their percentage weight, the first 15 countries for each thematic area. Note is also made of the total number of countries that provide researchers in each category.

The results differ little from those obtained in Figure 5, which leads us to understand that, generally speaking, researchers work within their more immediate geographic setting. Especially interesting is the preference US researchers have for relational and quality-linked topics and the propensity of UK researchers for a more general subject matter and for aspects related to production programming and logistics.

\section{--- FIGURE 6 ---}

\section{Conclusions}

An analysis of the papers indexed in the Business Source Complete leads to the conclusion that supply chain management in the automotive industry has become consolidated, especially since the beginning of the new millennium, as an area of great interest for researchers. It has been covered by a raft of journals, with some of the more salient ones being those focusing on operations management, and although one cannot say there has been an increase in the latter's output, neither has there been any decline whatsoever.

\footnotetext{
${ }^{6}$ http://oica.net/category/production-statistics/
} 
We have seen how the content and contribution of the papers may be analysed according to new focal points or thematic areas. Each one of them has revealed tendencies and potential opportunities or challenges, although generally speaking it is worth noting the importance of adopting increasingly more ample perspectives of analysis, which permit the study of whole chains rather than isolated links within those chains, or which break the tendency to study the supply chains separately from the distribution chains of assemblers.

If we consider the methodological approaches used, the pre-eminence of case studies over surveys suggests it is a field of study that is still at an incipient stage. Many of the papers have an exploratory nature and are of a theoretical construction, being fewer those that adopt a confirmatory perspective. A great challenge within this field lies in the difficulty of obtaining representative samples when the unit of analysis goes beyond the company itself. Obtaining valid and reliable information at supply chain level, for example, implies the cooperation of different agents involved in the same, and this is always complicated. Another major problem involves the scant secondary information sources available to researchers. The information contained in public databases or in the reports that the firms themselves or business associations publish focuses largely on financial or commercial aspects, with minimal data of interest for the analysis of supply chains. This means the majority of the papers have a static nature. There is a need for initiatives that systematically contain information on the sector within the sphere of inter-organisational relations.

The analyses conducted reflect US and UK leadership in this field of research, revealing that the interest aroused by this matter in a determined geographic context is closely related to the economic and social importance the automotive industry has in that setting. A challenge in this sense lies in the need to produce international empirical papers that allow comparing different contexts and circumstances, identifying each one's peculiarities and specificities and those aspects that are truly generalisable.

Naturally enough, the analysis conducted here is not without its limitations, and these pose challenges for the future development of this research. We should first draw attention to the fact we have used a single database. Although we do consider it to be reasonably representative, there are media that fall outside its scope. Secondly, and once again related to the choice of database, we have focused largely on journals of an international scope and mostly published in English, which means that others of a more local nature have been omitted. Thirdly, we have dealt exclusively with scholarly papers, omitting other channels of scientific disclosure, such as books or working documents. Nonetheless, and given the nature of the tendencies identified in our analysis, we do not believe that these are seriously conditioned by the biases these limitations involve. 


\section{References}

ACEA (2011): "The automobile industry pocket guide", ACEA Communications Department, http://www.acea.be/collection/publications

Aitken, J. and Murray, A. (2010): "Crash repair in the UK: reusing salvaged parts in car repair centres", International Journal of Logistics: Research \& Applications, 13(5): 359-372.

Alfalla-Luque, R. and Medina-Lopez, C. (2009): "Supply Chain Management: Unheard of in the 1970s, core to today's company", Business History, 51(2): 202-221.

Ansari, A. and Modarress, B. (1986): "Just-in-Time Purchasing: Problems and Solutions", International Journal of Purchasing and Materials Management,22(2): 11-15.

Ansari, A. and Modarress, B. (1988): "JIT Purchasing as a Quality and Productivity Centre", International Journal of Production Research, 26(1): 19-26.

Arshinder, A.K. and Deshmukh, S.G. (2007): "Coordination in supply chains: an evaluation using fuzzy logic", Production Planning \& Control, 18(5): 420-435.

Becker, J., Vilkov, L., Weiß, B. and Winkelmann, A. (2010): "A model based approach for calculating the process driven business value of RFID investments", International Journal of Production Economics, 127(2): 358-371.

Bertoni, M. and Larsson, A. (2011): "Engineering 2.0: an approach to support cross-functional teams in overcoming knowledge-sharing barriers in PSS design", International Journal of Product Development, 15(1-3): 115-134.

Bevan, J. (1987): "What Is Co-Makership", International Journal of Quality \& Reliability Management, 4(3): 47-56.

Bhattacharya, A.K., Coleman, J.L., Brace, G. and Kelly, P.J. (1996): “The Structure Conundrum in Supply Chain Management”, International Journal of Logistics Management, 7(1): 39-48.

Bhote, K.R. (1989): Strategic Supply Management: A Blueprint for Revitalising the ManufacturerSupplier Partnership, American Management Association, New York.

Blackhurst, J.V., Scheibe, K.P. and Johnson, D.J. (2008): "Supplier risk assessment and monitoring for the automotive industry", International Journal of Physical Distribution \& Logistics Management, 38(2): 143-165.

Bryman, A. (1989): Research Methods and Organization Studies, Unwin Hyman Ltd., London.

Burgess, K., Singh, P. and Koroglu, R. (2006): "Supply chain management: a structured literature review and implications for future research", International Journal of Operations \& Production Management, 26 (7): 703-729.

Canbolat, Y.B., Gupta, G., Matera, S. and Chelst, K. (2008): "Analysing risk in sourcing design and manufacture of components and sub-systems to emerging markets", International Journal of Production Research, 46(18): 5145-5164.

Chen, I.J. and Paulraj, A. (2004): "Towards a theory of supply chain management: the constructs and measurements", Journal of Operations Management, 22(2): 119-150.

Chen, Y.J. (2011): "Structured methodology for supplier selection and evaluation in a supply chain", Information Sciences, 181(9): 1651-1670.

Chi, L., Holsapple, C.W. and Srinivasan, C. (2008): "Digital Systems, Partnership Networks, and Competition: The Co-Evolution of IOS Use and Network Position as Antecedents of Competitive Action”, Journal of Organizational Computing \& Electronic Commerce, 1(18): 61-94.

Cigolini, R., Cozzi, M. and Perona, M. (2004): "A new framework for supply chain management: conceptual model and empirical test", International Journal of Operations and production Management, 24 (1): 7-14.

Collins, R. and Bechler, K. (1999): "Outsourcing in the Chemical and Automotive Industries: Choice of Competitive Imperative?”, Journal of Supply Chain Management, 35(4): 4-11.

Coronado Mondragón, A.E. and Lyons, A.C. (2008): "Investigating the implications of extending synchronized sequencing in automotive supply chains: the case of suppliers in the European automotive sector", International Journal of Production Research, 46(11): 2867-2888.

Cousins, P.D. and Crone, M.J. (2003): "Strategic models for the development of obligation based interfirm relationships: A study of the UK automotive industry", International Journal of Operations \& Production Management, 23(11): 1447-1474.

Creswell, J.W. (1994): Research Design: Qualitative \& Quantitative Approaches, Sage Publications, California.

Croom, S.R., Romano, P. and Giannakis, M. (2000): "Supply chain management: an analytical framework for critical literature review", European Journal of Purchasing and Supply Management, 6(1): 67-83.

http://mc.manuscriptcentral.com/tprs Email: ijpr@tandf.co.uk 
Curkovic, S. Vickery, S. and Droge, C. (2000): "Quality-related Action Programs: Their Impact on Quality Performance and Firm Performance", Decision Sciences, 31(4): 885-905.

Danese, P. and Vinelli, A. (2009): "Supplier network relocation in a capital-intensive context: a longitudinal case study", International Journal of Production Research, 47(4): 1105-1125.

Delmas, M. and Montiel, I. (2009): "Greening the Supply Chain: When Is Customer Pressure Effective?", Journal of Economics \& Management Strategy, 18(1): 171-201.

Dong-Hua, W. and Zailani, S. (2011): "Supply Chain Relationships and Design Quality: The Moderating Effect of Organization Culture", International Journal of Management, 28(4): 36-46.

Doran, D., Hill, A., Hwang, K. and Jacob, G. (2007): "Supply chain modularisation: Cases from the French automobile industry", International Journal of Production Economics, 106(1): 2-11.

Dyer, J.H. and Singh, H. (1998): "The Relational View: Cooperative Strategy and Sources of Interorganizational Competitive Advantage", Academy of Management Review, 23(4): 660-679.

Easterby-Smith, M., Thorpe, R. and Lowe, A. (1991): Management Research. An Introduction, Sage, London.

Eisenhardt, K.M. (1989): "Building Theories from Case Study Research”, Academy of Management Review, 14(4): 532-550.

Ellram, L.M. and Cooper, M.C. (1990): "Supply chain management, partnerships and the shipper-third party relationship", International Journal of Logistics Management, 1(2): 1-10.

Flynn, B.B., Sakakibara, S., Schroeder, R.G., Bates, K.A. and Flynn, E.J. (1990): "Empirical Research Methods in Operations Management", Journal of Operations Management, 9(2): 250-284.

Foster, S.T. (2008): “Towards an understanding of supply chain quality management", Journal of Operations Management, 26(4): 461-467.

Giunipero, L.C.; Hooker, R.E., Joseph-Matthews, S., Yoon, T.E. , Tom E. and Brudvig, S. (2008: “A decade of SCM literature: past, present and future implications", Journal of Supply Chain Management, 44(4): 66-86.

Göl, H. and Çatay, B. (2007): "Third-party logistics provider selection: insights from a Turkish automotive company", Supply Chain Management, 12(6): 379-384.

González-Benito, J. and Spring, M. (2000): "JIT Purchasing in the Spanish Auto Components Industry: Implementation Patterns and Perceived Benefits", International Journal of Operations and Production Management, 20(2), 1038-1061.

Grefen, P., Mehandjiev, N., Kouvas, G., Weichhart, G. and Eshuis R. (2009): "Dynamic business network process management in instant virtual enterprises", Computers in Industry, 60(2), 86-103.

Hammami, R., Frein, Y. and Hadj-Alouane, A.B. (2009): "A strategic-tactical model for the supply chain design in the delocalization context: Mathematical formulation and a case study", International Journal of Production Economics, 122(1): 351-365.

Handfield, R., Sroufe, R. and Walton, S. (2005): "Integrating environmental management and supply chain strategies", Business Strategy \& the Environment, 14(1), 1-19.

Harland, C.M. (1996): "Supply chain management: Relationships, chains and networks", British Journal of Management, 7 (special issue): s63-s80.

Hatani, F. (2009): "The logic of spillover interception: The impact of global supply chains in China", Journal of World Business, 44(2): 158-166.

Hill, K., Cooper, A. and Menk, D.M. (2010): "Contribution of the Automotive Industry to the Economies of All Fifty States and the United States", Center for Automotive Research, http://www.cargroup.org/publications.html

Ho, D.C.K., Au, K.F. and Newton, E. (2002): "Empirical research on supply chain management: a critical review and recommendations", International Journal of Production Research, 40(17): 4415-4430.

Holweg, M. and Miemczyk, J. (2002): "Logistics in the 'three-day car' age", International Journal of Physical Distribution \& Logistics Management, 32(10): 829-850.

Jensen, M.C. and Meckling, W.H. (1976): "Theory of the Firm: Managerial Behavior, Agency Costs and Ownership Structure", Journal of Financial Economics, 3: 305-360.

Johansson, E. (2009): "Information management for materials supply systems design", International Journal of Production Research, 47(8): 2217-2229.

Johnsen, T. and Ford, D. (2005): "At the receiving end of supply network intervention: The view from an automotive first tier supplier", Journal of Purchasing \& Supply Management, 11(4): 183-192.

Johnson, D. (2002): "Empirical study of second-tier automotive suppliers achieving QS-9000", International Journal of Operations \& Production Management, 22(8): 902-928.

Johnston, R. and Lawrence, P. (1988): "Beyond Vertical Integration: The Rise of the Value-Adding Partnership", Harvard Business Review, 66(4): 94-101. 
Klingenberg, W. and Boksma, J.D. (2007): "A conceptual framework for outsourcing of materials handling activities in automotive: differentiation and implementation", International Journal of Production Research, 48(16): 4877-4899.

Krause, D.R., Handfield, R.B. and Tyler, B.B. (2007): "The relationship between supplier development, social capital accumulation and performance improvement", Journal of Operations Management, 25(2): 528-545.

Kumar, S. and Putnam, V. (2008): "Cradle to cradle: Reverse logistics strategies and opportunities across three industry sectors", International Journal of Production Economics, 115(2): 305-315.

Lamming, R. (1993): Beyond Partnership: Strategies for Innovation and Lean Supply, Prentice-Hall, London.

Leenders, M.R. and Blenkhorn, D.L. (1988): Reverse Marketing: The New Buyer-Supplier Relationship, The Free Press, New York.

Lockström, M., Schadel, J., Harrison, N., Moser, R. and Malhotra, M.K. (2010): “Antecedents to supplier integration in the automotive industry: A multiple-case study of foreign subsidiaries in China", Journal of Operations Management, 28(3): 240-256.

McCutcheon, D.M. and Meredith, J.R. (1993): "Conducting Case Study Research in Operations Management", Journal of Operations Management, 11(3): 239-256.

Mentzer, J.T., DeWitt, W., Keebler, J.S., Min, S., Nix, N.W., Smith, C.D. and Zacharia, Z.G. (2001): "Defining Supply Chain Management", Journal of Business Logistics, 22(2): 1-25.

Meredith, J.R., Raturi, A., Amoako-Gyampah, K. and Kaplan, B. (1989): "Alternative Research Paradigms in Operations", Journal of Operations Management, 8(4): 297-326.

Meredith, J.R., Steward, M.D. and Lewis, B.R. (2011): "Knowledge dissemination in operations management: Published perceptions versus academic reality", Omega, 39(4): 435-446.

Min, S. and Mentzer, J.T. (2004): "Developming and measuring supply chain management concepts", Journal of Business Logistics, 25(1): 63-99

Reck, R.F. and Long, B.G., 1988. Purchasing: A competitive weapon, International Journal of Purchasing and Materials Management, 24 (3): 2-8.

Reichhart, A. and Holweg, M. (2006): "What Is the Right Supplier Park for Your Supply Chain?", Supply Chain Forum: International Journal, 7(1): 4-13.

Roehrich, J.K., Parry, G.C. and Graves, A.P. (2011): "Implementing build-to-order strategies: enablers and barriers in the European automotive industry", International Journal of Automotive Technology \& Management, 11(3): 221-235.

Sako, M. (1992): Prices, quality, and trust: inter-firm relations in Britain and Japan, Cambridge University Press, Cambridge.

Samaranayake, P. and Toncich, D. (2007): "Integration of production planning, Project management and logistics systems for supply chain management", International Journal of Production Research, 45(22): 5417-5447.

Scannell, T.V., Vickery, S.K. and Dröge, C.L. (2000): "Upstream supply chain management and competitive performance in the automotive supply industry", Journal of Business Logistics, 21(1): 2348.

Soni G. and Kodali, R. (2011): “A critical analysis of supply chain management content in empirical research", Business Process Management Journal, 17(2): 238-266.

Spekman, R.E., Kamauff, J.W. and Salmond, D.J., 1992. At last purchasing is becoming strategic, Long Range Planning, 27(2): 76-84.

Theoharakis, V., Voss, C., Hadjinicola, G.C. and Soteriou, A.C. (2007): "Insights into factors affecting Production and Operations Management (POM) journal evaluation", Journal of Operations Management, 25(4): 932-955.

Thompson, M. (1996): "Effective purchasing strategy: the untapped source of competitiveness", Supply Chain Management, 1(3): 6-8.

Tracey, M., Fite, R.W. and Sutton, M.J. (2004): “An explanatory model and measurement instrument: A guide to supply chain management research and applications", Mid-American Journal of Business, 19(2): 53-70.

Turnbull, P., Oliver, N. and Wilkinson, B. (1992): "Buyer-supplier relations in the UK automotive industry: strategic implications of the Japanese manufacturing model", Strategic Management Journal, 13(2): 159-168.

Vujasinovic, M., Ivezic, N., Kulvatunyou, B., Barkmeyer, E., Missikoff, M., Taglino, F., Marjanovic, Z. and Miletic, I. (2009): "A semantic-mediation architecture for interoperable supply-chain applications", International Journal of Computer Integrated Manufacturing, 22(6): 549-561.

Waters-Fuller, N. (1995): "Just-in-Time Purchasing and Supply : A Review of the Literature", International Journal of Operations and Production Management, 15(9): 220-236. 
Welch, J.A. and Nayak, P.R. (1992): "Strategic sourcing: a progressive approach to the make-or-buy decision", Academy of Management Executive, 6(1): 23-31.

Williamson, O.E. (1979): "Transaction-Cost Economics: The Governance of Contractual Relations", Journal of Law and Economics, 22(2): 233-261.

Wong, C.Y., Boonitt, S. and Wong, C.W.Y. (2011): "The contingency effects of environmental uncertainty on the relationship between supply chain integration and operational performance", Journal of Operations Management, 29(6): 604-615.

Wynstra, F., von Corswant, F. and Wetzels, M. (2010): "In Chains? Co-design - from an automaker perspective", Journal of Product Innovation Management, 27(5): 625-639.

Yin, R.K. (1989): Case Study Research: Design and Methods, Sage Publications, Beverly Hills.

Zhang, X., van Donk, D.P. and van der Vaart, T. (2011): "Does ICT influence supply chain management and performance?: A review of survey-based research", International Journal of Operations and Production Management, 31(11): 1215-1247.

Zirpoli, F. and Caputo, M. (2002): "The nature of buyer-supplier relationships in co-design: The Italian auto industry case", International Journal of Operations \& Production Management, 22(12): 13891410 . 
Table 1. Distribution of papers by journal

\begin{tabular}{|c|c|c|c|}
\hline Review & Frequency & $\%$ & Accumulated \% \\
\hline International Journal of Automotive Technology \& Management & 38 & 9,40 & 9,4 \\
\hline International Journal of Production Research & 32 & 7,90 & 17,3 \\
\hline International Journal of Production Economics & 24 & 5,90 & 23,3 \\
\hline $\begin{array}{l}\text { International Journal of Operations \& Production Management } \\
\text { International Journal of Physical Distribution \& Logistics }\end{array}$ & 18 & 4,50 & 27,7 \\
\hline Management & 18 & 4,50 & 32,2 \\
\hline Journal of Operations Management & 14 & 3,50 & 35,6 \\
\hline Supply Chain Management & 12 & 3,00 & 38,6 \\
\hline Journal of Supply Chain Management & 11 & 2,70 & 41,3 \\
\hline Industrial Management \& Data Systems & 10 & 2,50 & 43,8 \\
\hline International Journal of Logistics Management & 10 & 2,50 & 46,3 \\
\hline International Journal of Logistics: Research \& Applications & 10 & 2,50 & 48,8 \\
\hline Production Planning \& Control & 8 & 2,00 & 50,7 \\
\hline European Journal of Operational Research & 7 & 1,70 & 52,5 \\
\hline International Journal of Technology Management & 7 & 1,70 & 54,2 \\
\hline Journal of Manufacturing Technology Management & 7 & 1,70 & 55,9 \\
\hline Journal of Purchasing \& Supply Management & 6 & 1,50 & 57,4 \\
\hline IEEE Transactions on Engineering Management & 5 & 1,20 & 58,7 \\
\hline International Journal of Management & 5 & 1,20 & 59,9 \\
\hline Journal of Cleaner Production & 5 & 1,20 & 61,1 \\
\hline Computers in Industry & 4 & 1,00 & 62,1 \\
\hline Industrial Marketing Management & 4 & 1,00 & 63,1 \\
\hline Journal of Business Logistics & 4 & 1,00 & 64,1 \\
\hline Others & 145 & 35,9 & 100,0 \\
\hline
\end{tabular}

Table 2. Distribution of papers by themes

\begin{tabular}{lcc}
\multicolumn{1}{c}{ Thematic area } & $\begin{array}{c}\text { Number of } \\
\text { articles }\end{array}$ & Percentage \\
\hline 1. General theme & 79 & $17.06 \%$ \\
2. Relational issues (cooperation and integration) & 84 & $18.14 \%$ \\
3. Product design and development & 41 & $8.86 \%$ \\
4. Supplier selection and evaluation & 18 & $3.89 \%$ \\
5. Supplier development & 9 & $1.94 \%$ \\
6. Quality, reliability and risk management & 41 & $8.86 \%$ \\
7. Production scheduling and logistics & 89 & $19.22 \%$ \\
8. Environmental management & 33 & $7.13 \%$ \\
9. Information systems and technology & 69 & $14.90 \%$ \\
\hline
\end{tabular}




\section{Figure 1. Chronological distribution of the papers}

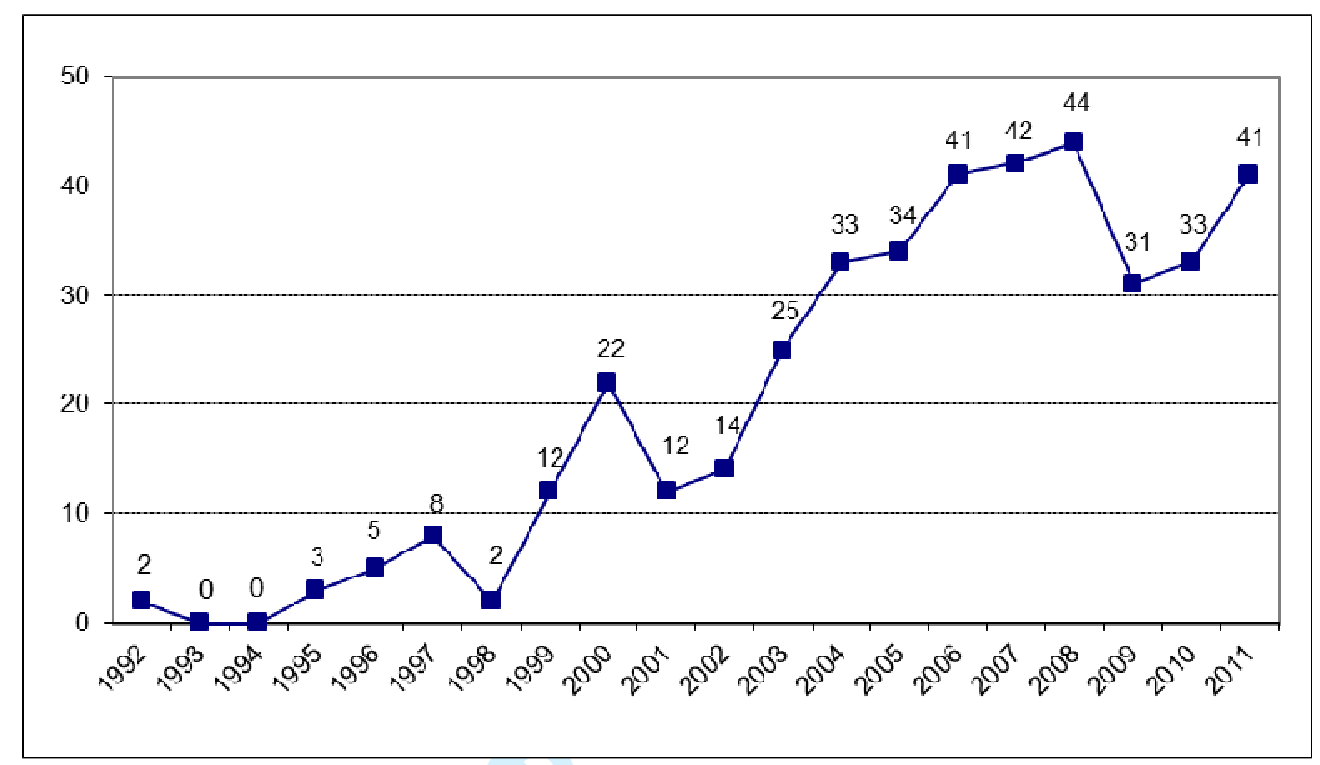

Figure 2.Thematic areas chosen to classify the papers

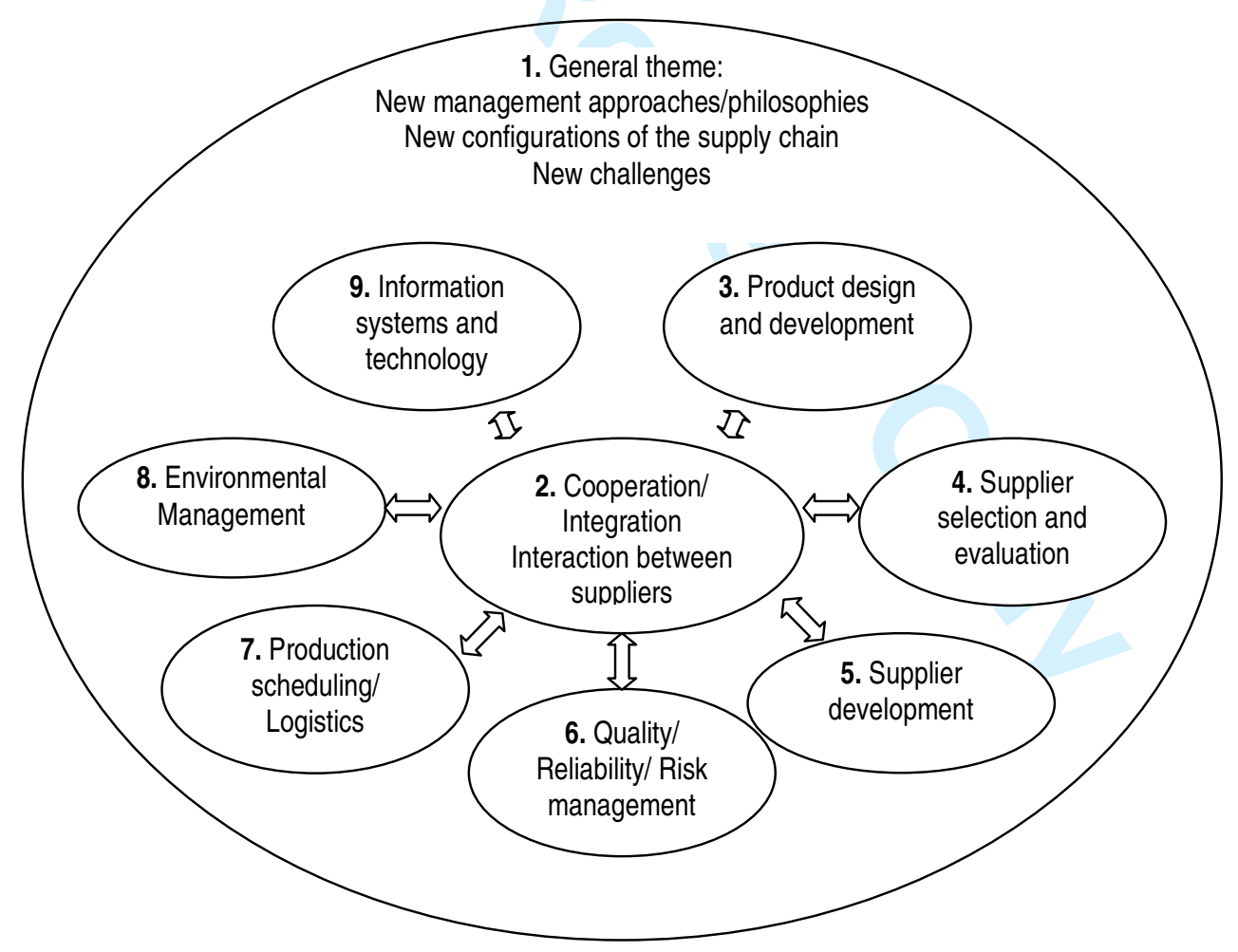

http://mc.manuscriptcentral.coh/tprs Email: ijpr@tandf.co.uk 
Figure 3. Chronological distribution by thematic area

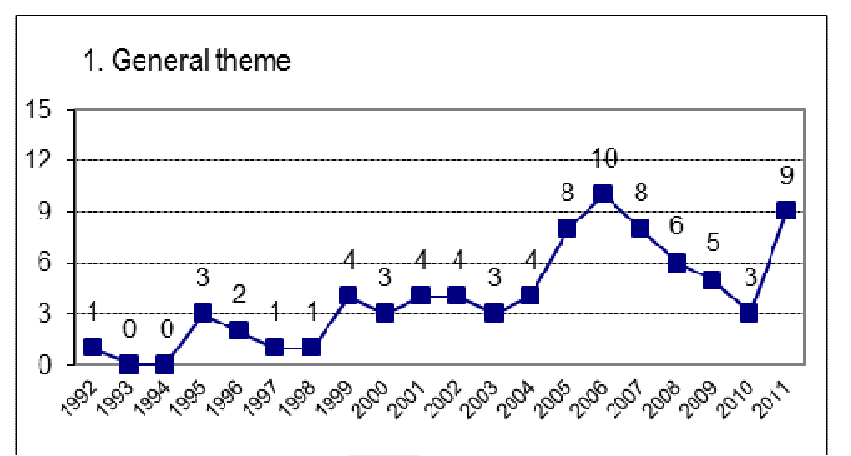

2. Relational issues (cooperation and integration)

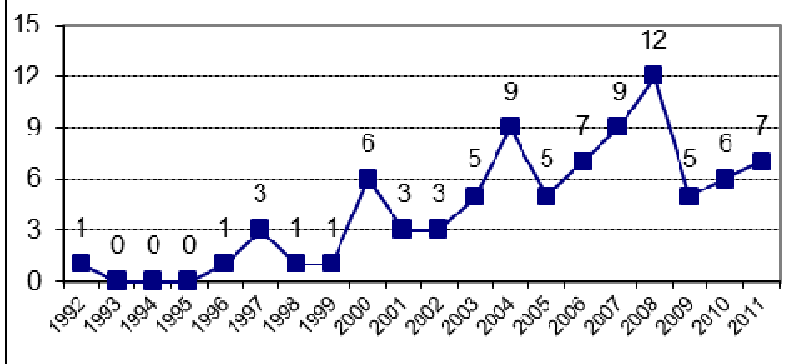

3. Product design and development

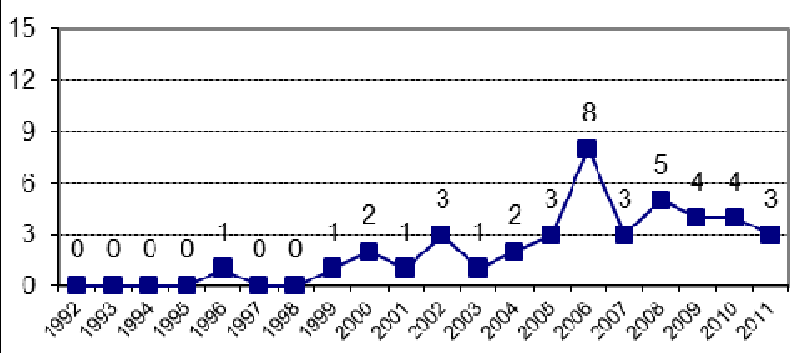

5. Supplier development

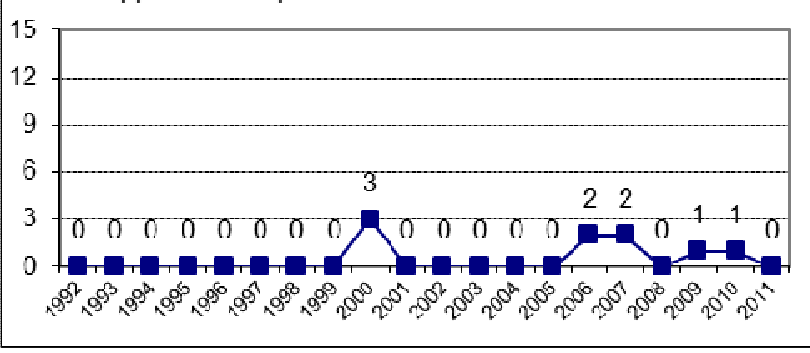

7. Production scheduling and logistics

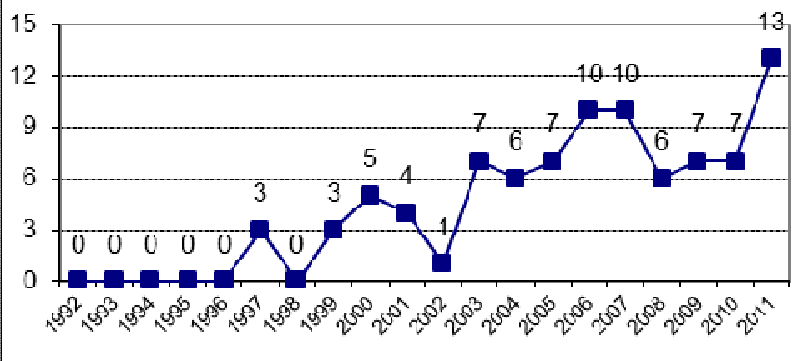

9. Information systems and technology

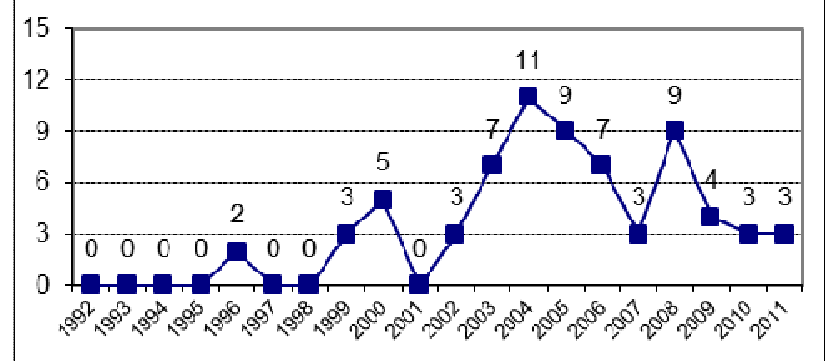

4. Supplier selection and evaluation

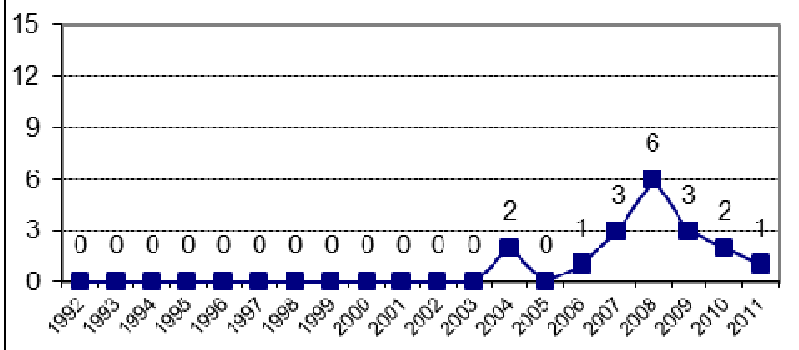

6. Quality, reliability and risk management

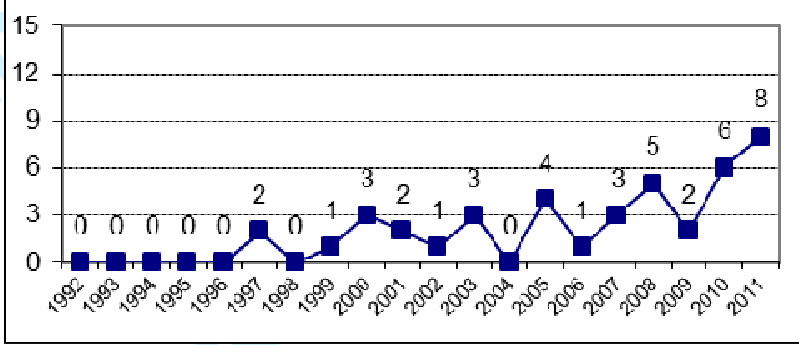

8. Environmental management

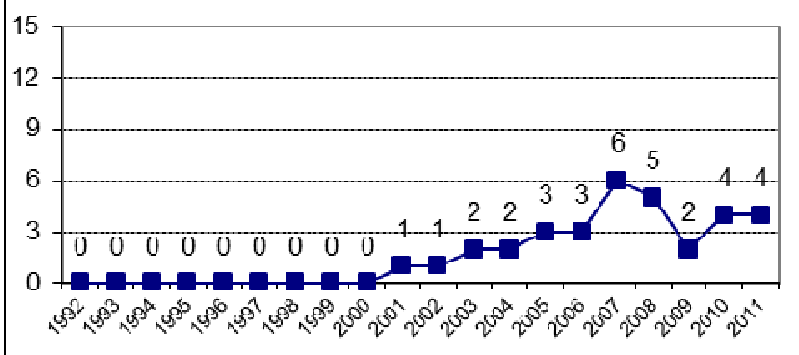

All thematics (accumulative)

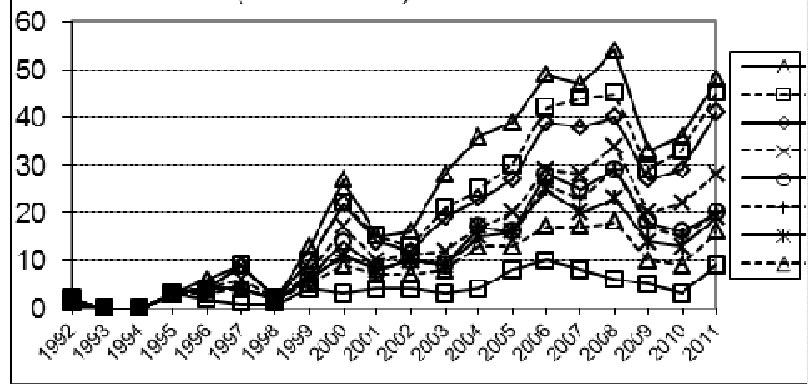

http://mc.manuscriptcentral.com/tprs Email: ijpr@tandf.co.uk 

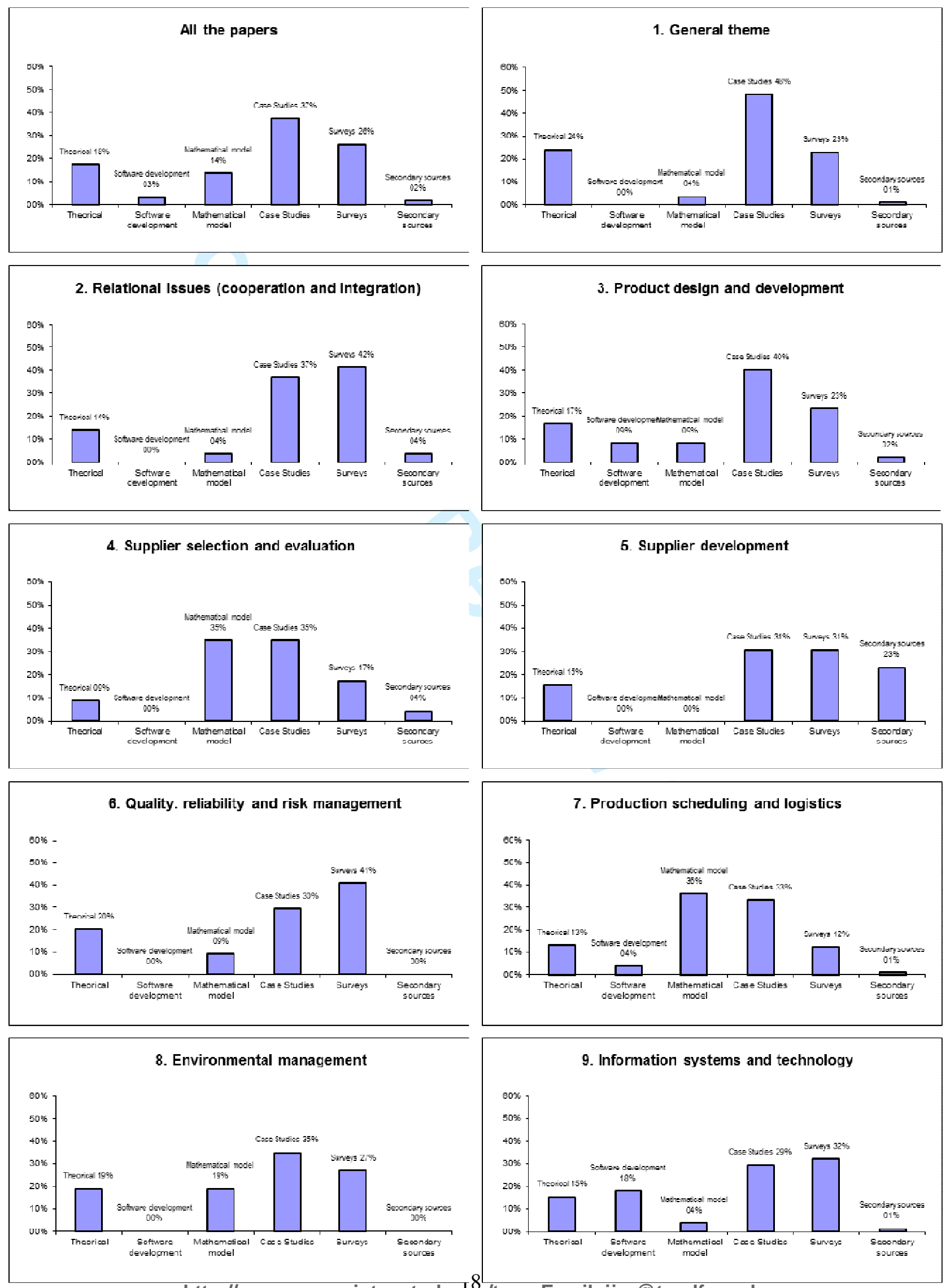
Figure 5.Scope of research
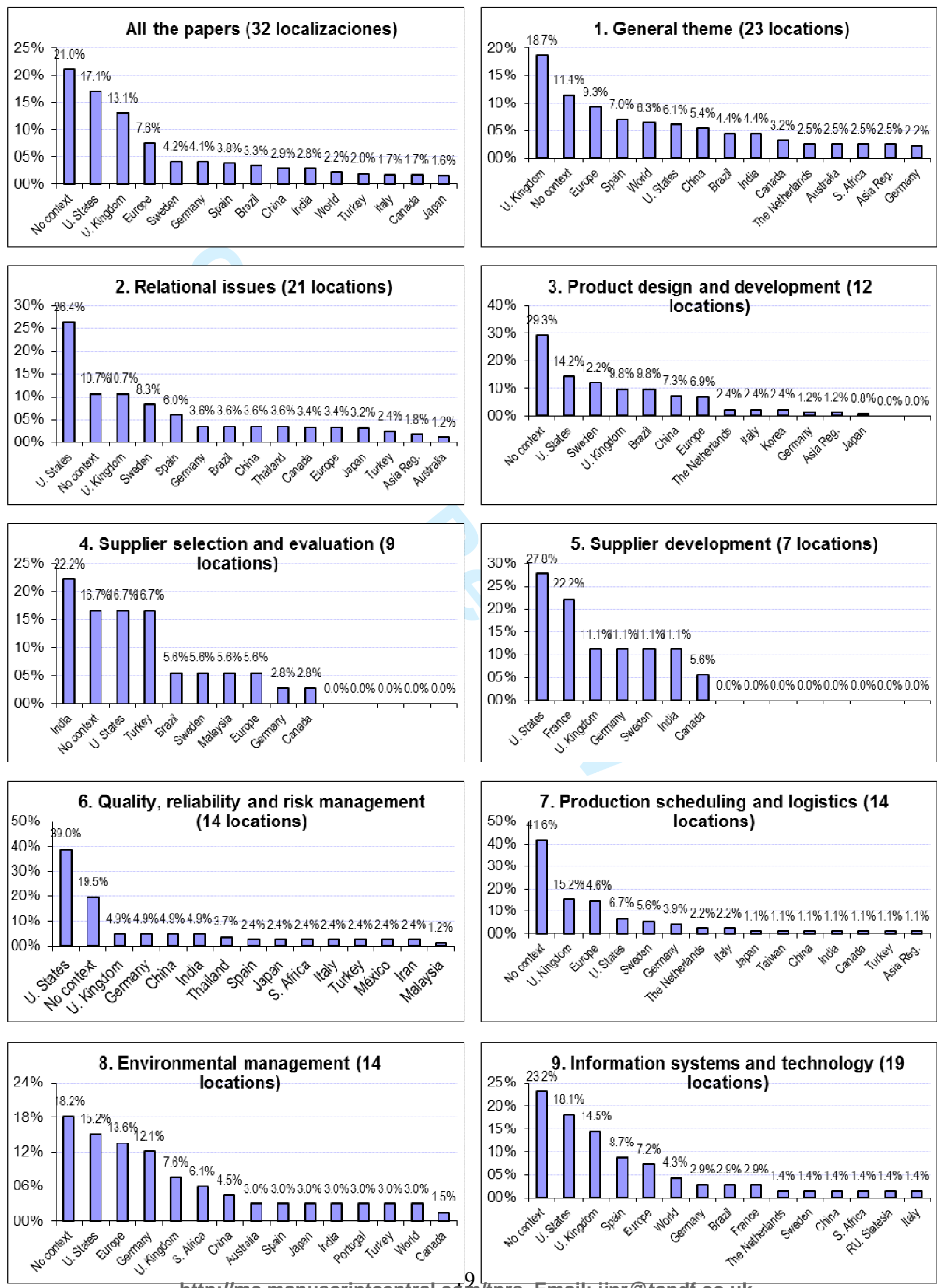

http://mc.manuscriptcentral.com/tprs Email: ijpr@tandf.co.uk 
Figure 6.Geographic provenance of researchers
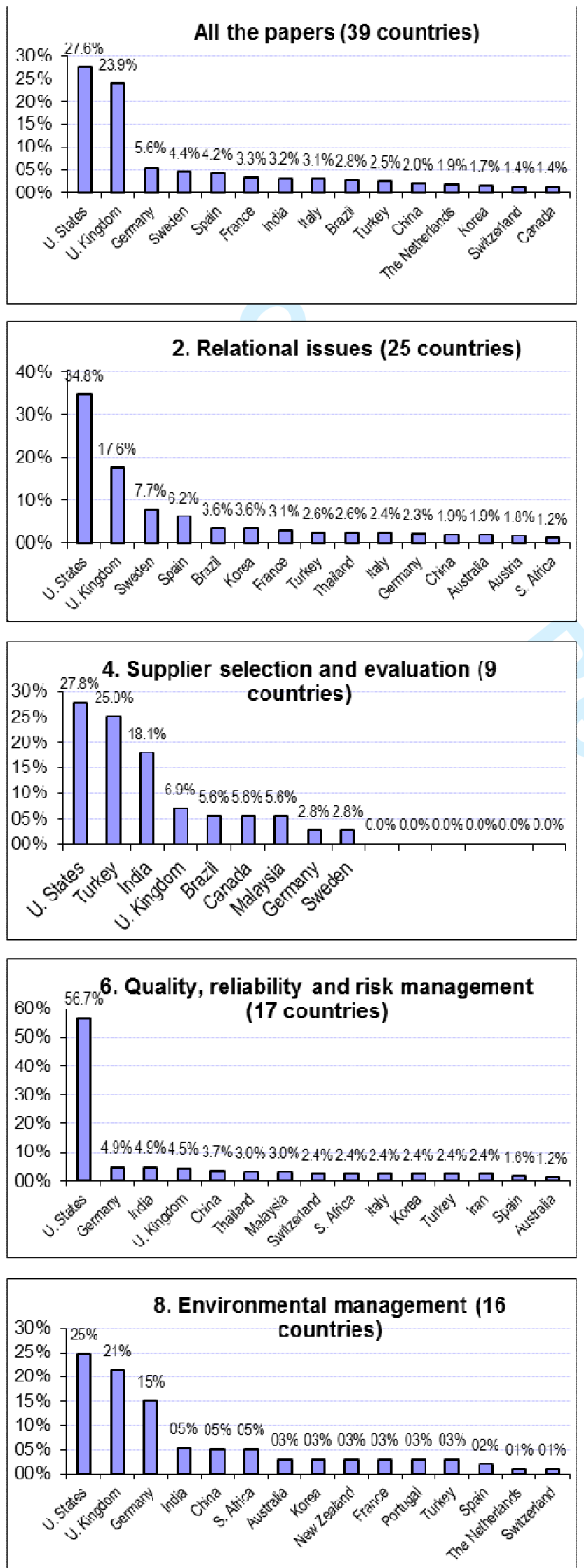

1. General theme (24 countries)

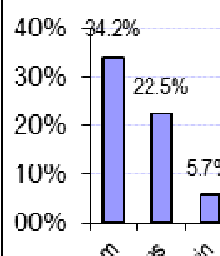
1. General theme (24 countries)

3 का
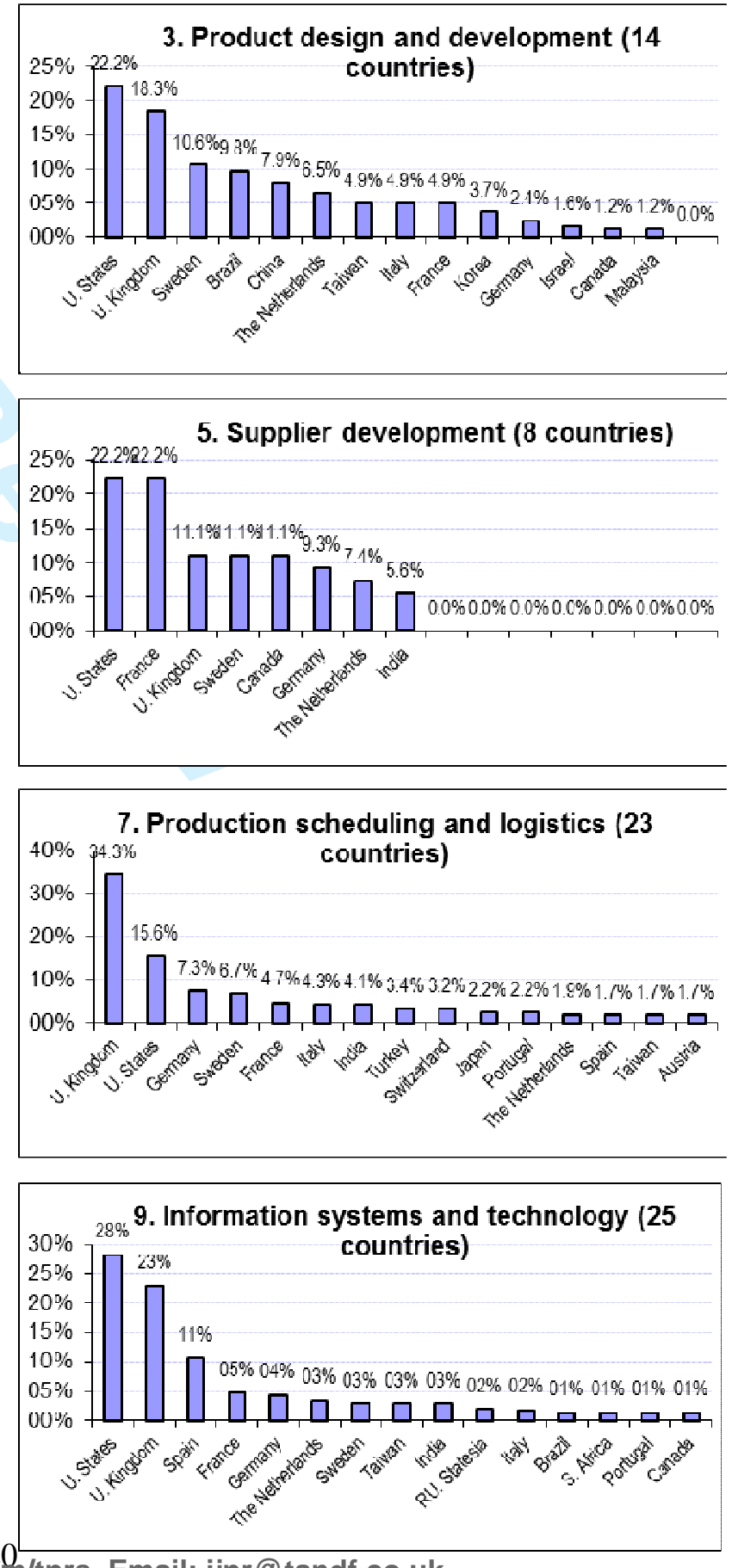